\title{
En gjendiktet aura? Noen bemerkninger til Wisława Szymborskas lyrikk i Norge
}

\section{An Re-created Aura? A Few Remarks on Wisława Szymborska's Lyric in Norway}

\author{
Aleksandra Wilkus-Wyrwa
}

\begin{abstract}
The purpose of this article is to make a comparative analysis of Wisława Szymborska's poem "Utopia" with its Norwegian translation from 1996. Since the original piece in Polish has a very specific construction, which is based on the use of idioms and puns, it is difficult to transfer it to virtually any language. The key to the critical commentary of Ole Michael Selberg's translation is the notion of "aura", borrowed from Walter Benjamin. As a tool for aesthetic analysis it corresponds well with changes that occur in his version of "Utopia". At the same time, this article gives an insight into what kind of place does Wisława Szymborska's work find in the Norwegian literary consciousness.
\end{abstract}

\section{Keywords}

translation, poetry, Wisława Szymborska, Nobelprize, aura, Walter Benjamin, idiomatic phrase, pun 
For poetry that with ironic precision allows the historical and biological context to come to light in fragments of human reality. ${ }^{1}$.

Denne begrunnelsen fikk vi høre da Wisława Szymborska ble tildelt nobelprisen i litteratur i 1996. Det som likevel synes å være mest interessant for lesere er snarere spørsmålet om konsekvenser en slik verdensberømmelse medfører for resepsjonen av Szymborskas lyrikk utenfor Polen. I følgende bidrag vil jeg diskutere dette spørsmålet med hovedtyngden lagt på Ole Michael Selbergs gjendiktning av verket «Utopia». Ikke minst er innleggets formål å sette den estetikken som vi møtes med i utgangsteksten sammen med diktets norske gjengivelse. Gjennom en komparativ fortolkning vil jeg nemlig nå frem til måten Szymborskas «Utopia», og i bredere forstand hennes forfatterskap, kan leses i Norge på. Man skal vel ikke glemme at diktoversettelse faller inn i den type språklig og estetisk utfordring hvor modellgjendikter ikke bare baserer seg på rent filologisk kunnskap, men har også de ikke-verbale faktorene i bakhodet. En sammenlignende gjendiktningsanalyse setter omsider pris på alle disse ytre mekanismene og bidrar dermed til å fullstendiggjøre et upresist rom mellom originalen og målteksten, som noen gjerne kaller MELLOMROM (VIKØY, STRØM, ROKSETH 2007: 9).

Metodologisk sett streber følgende undersøkelse mot å fange opp originalens AURA, for så å jakte på dens nærvær i målteksten. Å bruke AURA-begrepet som et nyttig analyseredskap fremstår likevel som en utfordring. Grunnen til det er at Walter Benjamin, den trolig mest kjente banebryteren innen auraens forskning, henviser til dette fenomenet i flere av sine tekster, og attpåtil i flere ulike sammenhenger. Etter å ha gått gjennom Benjamins kritiske lesning, vil jeg gjøre auraen til en normativ kategori og sjekke ved hjelp av den hvor mye av originalens unike karakter blir gjenkjennelig i måldiktet.

Til syvende og sist betrakter jeg dette innlegget som et lite skritt fremover mot utviklingen av komparativ oversettelseskritik Skandinavia. Riktignok må det markeres at antallet norske publikasjoner vedrørende oversettelsens litteraturvitenskapelige aspekter er blitt synlig større enn før², men ledende rolle synes fortsatt å høre til Sverige. Grunnet sitt periferiske resepsjonsomfang står skandinaviske språk heller ikke i spissen for spredning av oversatt verdenslitteratur. Derfor formoder jeg imidlertid at å sette disse litteraturkritiske problemene under debatt i den delen av verden er en enda viktigere utfordring, særlig med hensyn til fagfeltets generelle fremgang.

1 Sitatet hentet fra nobelprisens offisielle nettside: http://www.nobelprize.org/nobel_prizes/literature/ laureates/1996/szymborska-facts.html (tilgjengelig 1.06.2016).

2 Dette gjelder både bøker og tidsskrifter. La meg navne bare noen av dem: Mellom, Norske kritikeres fagtidsskrift, Vagant, Vinduet, Bøygen som alle inneholder minst én temabolk om oversettelse, og serien Mellomrom - Mellomrom: Tolv tekster om oversettelse (2007), samt Mellomrom II: Omsetjaren Olav H. Hauge (2009). 


\section{De (u)kjente - Wisława Szymborska i Norge}

Det innledende sitatet tyder på at Wisława Szymborskas navn ikke bare er lett gjenkjennelig i hjemlandet, men på bakgrunn av nobelprisen er hun teoretisk sett regnet blant de fremste og største forfatterne i verden. Denne lille damen med sigaretten i hånda ansett forresten for hennes attributt, ble kåret til denne elitære kretsen seksten år etter hennes eldre landsmann - Czesław Miłosz. Takket være denne doble suksessen har polsk litteratur trådt inn i verdens bevissthet for godt ${ }^{3}$. Men gir denne berømmelsen en faktisk garanti for popularitet og antall oversatte verk? Svaret lyder selvfølgelig «nei». Leter vi nemlig etter noen spor av polsk litteratur i Norge, viser det seg at det ikke er nobelprisen som bestemmer hvor stor anerkjennelse man oppnår utenfor hjemlandet. Videre kan man spekulere på om hver sjanger oversatt fra polsk (historiske romaner, romantisk eller modernistisk lyrikk o.l.) oppfattes som like leservennlig på norsk, men dette problemet krever kanskje en separat undersøkelse som ikke er bestanddelen av denne analysen.

Ovenstående merknad synes jeg iallfall er godt å få seg med når man snakker om de to nobelprisvinnerne på samme tid. Miłosz er dog kjent som både dikter, prosaforfatter, essayist og oversetter, mens Szymborska stort sett hele livet stod fast ved sin poetiske form ${ }^{4}$. Dette medfører noen forskjeller (for ikke å snakke om uvillig forfalskning) på den faktiske resepsjonsmessige kondisjonen av begge forfatterne i Norge. Et godt illustrerende eksempel er såframt antall diktsamlinger hvor deres navn dukker opp i: Fremfor alt trer Szymborska frem som en polsk spissdikter, helt på linje med Tadeusz Różewicz og Zbigniew Herbert (EGGEN, NAG 1967: 7), mens Miłosz’ poetiske tekster - sidestilt med de ovennevnte, virker sannelig marginale. Prosaen hans presenter seg derimot mye bedre, for ved siden av den kjente romanen Issadalen (overs. Ole Michael SELBERG 1981), er også hans filosofisk-essayistiske tekster tilgjengelige på norsk, bl.a.: Det trellbundne sinn (overs. Ivar Lunde 1981), Kunstens umoralskhet (overs. Ole Michael SELBERG 1981) og Erobringen av makten (overs. Ivar Lunde 1983).

A fordype seg i historien bak den polske litteraturens nærvær i Norge kan selvsagt være et betydelig forskningelement. Dette viser ikke bare generelle lanseringstendenser på det norske markedet, men introduserer ellers oversetterens skikkelser på en signifikant måte. Allikevel er mitt poeng heller ikke å gjenfortelle det som skjedde med polsk litteratur i Norge i løpet av de siste 150 år. Det jeg derimot påpeker er kildene hvor de interesserte kan finne frem til en tilfredsstillende oversikt over dette saksforholdet. Noen titler fortjener nemlig vår særlige oppmerksomhet, deriblant: Spesialnummer om Polen utgitt av tidsskriftet Ergo (3/96), antologien Den sjuande engelen. Eit utval frå polsk etterkrigslyrikk med en veldig kompleks innledning ved Martin NAG og Arnljot EGGEN (1967), Polen i norsk litteratur. Bibliografi av Ragnar RØED (1970) og Polsk litteratur i norsk oversettelse 1826-1989. En bibliografi skrevet i 1991 av Ole Michael SELBERG. Man kan

3 Bortsett fra disse to navnene var det også Henryk Sienkiewicz (1905) og Władysław Reymont (1924) som fikk nobelprisen i litteratur, men som pga. tidens løp er de i dag ikke så populære som Szymborska eller Miłosz.

4 Hun drev også lite grann med essayistikk, og i 1996 utkom en samling av hennes kritiske tekster om litteratur (Lektury nadobowiazkowe, 1996). 
vel si at å presentere landets litteraturhistorie er en naturlig reaksjon på å utfylle bokmarkedets hull. Men det som en kritiker setter enda større pris på, skjer innimellom de «forventede» utgivelsene (dvs. bearbeidet av - i dette tilfellet, norske forskere som kjenner polsk). Jeg ble følgelig veldig overrasket over et tilfeldig funn fra boken Hvordan lese en bok. Essays i Jo Ørjasæters oversettelse:

Hvis morsmålet [ditt] er polsk - eller hvis du i det minste behersker polsk (heldig for deg i så fall, for den mest storartede poesien i dette århundret er skrevet på det språket) - da ville jeg nevne navn som Leopold Staff, Czeslaw Milosz, Zbigniew Herbert og Wislawa Szymborska (BRODSKIJ 1997: 78).

Disse ordene bekrefter bare hvor stort potensial gjemmer seg bak polsk litteratur, og hvor viktig det er å minne de norske leserne om en verdifull litteratur skrevet i det språket som den største innvandrergruppen har som sitt morsmål. Alle detaljerte opplysninger ang. Norges befolkning finnes på ssb.no.

Når det gjelder selve Szymborska, har hun uten tvil fått seg en merkbar plass blant de storartede forfatterne som hittil overføres fra polsk til andre språk. Det egentlige vendepunktet i hennes internasjonale karriere starter iallfall for godt i 1959, da Karl Dedecius ${ }^{5}$ utgav antologien Lektion der Stille («En leksjon om stillhet») med utvalg av polsk lyrikk. Jevnført med denne debuten virker den første norske oversettelsen litt forsinket, men som Jan Erik Vold - Szymborskas beudrer, betoner:

Der var han [Martin Nag] som oppsporet diktene til Dagny Juel. Og lette fram glemte epistler av Rudolf Nilsen. Samt introduserte polakkene Witold Gombrowicz og Wislawa Szymborska i Norge, den siste nesten 30 år før hun fikk Nobelprisen. Som heller skulle ha gått til landsmannen Tadeusz Rozewicz, sier Martin (NAG 1997: 7).

Volds ord henviser til ovennevnte samling fra 1967, og her finner vi det første faktiske tegn på Szymborskas nærvær i Norge. Imidlertid krever dette sitatet en liten forklaring, og den finner vi forresten i samme bok. Selv om Nag viste stor forkjærlighet for Różewiczs forfatterskap, synes denne bemerkningen å være ganske urettferdig i akkurat den form som Vold presenterte. Imidlertid lyder hele utsagnet følgelig:

Også Tadeusz Rozewicz er av nobelpris-kvalitet; og dette er ikke sagt til forkleinelse for Wislawa Szymborska, slett ikke; det viser snarere hvor rik polsk etterkrigslyrikk har vært, - Zbigniew Herbert er en tredje nobelpris-kandidat! (NAG 1997: 122)

Uansett ens personlige preferanser er Szymborskas faste posisjon ikke noe å benekte. Dette ser man veldig tydelig i Sverige fordi blant mange språk er det nettopp hennes

$5 \quad$ Karl Dedecius (1921-2016) var en tysk oversetter av polsk og russisk litteratur. Takket være hans litterærkulturelle virksomhet, har polsk litteratur fått en betydelig status i Tyskland, og i tillegg etablerte han i 1980 Deutsches Polen-Institut som er opptatt av samarbeid og kulturformidling mellom Polen og Tyskland. Belønnet med bl.a. Den hvite ørns orden (2003) og Den tyske nasjonalpris (2010). 
svenske oversettelser litteraturkritikere verdsetter så høyt (Jf. f.eks.: BALBUS 1996: 7-19; MRÓWCZYŃSKA 2014: 13-15). Ikke nok å si, det er Szymborska selv som sympatiserte med Anders Bodegårds virksomhet, og etter å ha fått vite om Svenska Akademiens beslutning, reagerte hun veldig signifikant: «Det er Anders` skyld!» (BODEGÅRD 2014: 28), ropte hun i 1996 under oppholdet i Zakopane.

\section{Analysens teoretiske vy}

Et godt utgangspunkt for enhver litteraturkritisk tilnærming på en tekst er å granske hele utgivelsen helt fra omslagets ytterside. Vi kan like godt si at problemenes utlegging foregår i følgende tekst «fra oversikt til detalj». Det betyr rett og slett at jeg først fokuserer på boken som helhet, og så - gjennom nøkkelbegrepenes fremføring, når jeg selve kjernen, dvs. diktets innhold. Den måten å betrakte poesitolkning på streber forresten mot tendensen om å betrakte en litterær tekst som et dualistisk system ${ }^{6}$.

Til å begynne med gjør samlingen Utsikt med et sandkorn (over. og utvalg SELBERG 1996) et inntrykk av et gjennomtenkt prosjekt som gir leseren en reel sjanse til å bli kjent med Szymborskas grunnleggende skrivetrekk. I tillegg til 60 dikt som til sammen omfatter sju samlinger utgitt i periode 1957-1993, oppgir oversetteren en rekke kommentarer, en sammenfattet biografi, listen over polske dikttitler samt opplysninger om andre fremmedspråklige antologier rommende hennes poesi. Man bør heller ikke overse en annen interessant detalj, nemlig at Selbergs innsikt i Szymborskas kunstneriske skikkelse er nokså tilstrekkelig for å følge hennes vilje om ikke å oversette de tidligste diktene som hun hele livet har skammet seg over ${ }^{7}$. Det faktum at Selberg ikke bare tar hensyn til hennes konkrete forfatterskap, men også til den litteraturhistoriske konteksten hun var forankret i, får sin bekreftelse i ulike noter og etterordet til samlingen fra 1996 (SELBERG 1991).

Videre faller oss i øynene en helt grunnleggende formulering fra omslaget som lyder: «Gjendiktet fra polsk av Ole Michael Selberg». Ordet GJENDIKNING synes å være en helt forståelig term for de norsktalende ${ }^{8}$, men for å gjennomføre en dyktig analyse av et oversatt verk, bør man likevel stanse litt for å sjekke ut hvilke faktiske konsekvenser denne slående merknaden medfører. For det første oppfattes GJENDIKTNING nesten synonymt til ordet «oversettelse». Det er faktisk ikke lett å sette et tydelig skilletegn mellom dem, men til tross for innviklet nomenklatur kommer bl.a. kritikeren Henning Hagerup med en verdifull merknad i et av essayene sine:

6 Kittang bruker betegnelsen «en dualistisk oppbygging», noe som viser til leseprosessens to nivåer. Etter Kittang kan vi følgelig oppfatte en litterær tekst som et meningsverk («et system av betydninger»). Den påstanden insisterer at etter det første møtet med et dikt (tydning; en tekst forstått som et rent sanselige, språklig eller ordrett objekt) forekommer dets nærlesning, dvs. tolkning. Disse to etappene får oss til tekstens totale, intersubjektive mening. (Jf. KITTANG, AARSETH 1998: 11-14).

7 Her har jeg på tanke fotnoten til etterordet fra Utsikt med et sandkorn, hvor det står: «Szymborska har stort sett unnlatt å trykke opp igjen noe fra de to første samlingene, Derfor lever vi, 1952 og Spørsmål til meg selv, 1954». Op.cit. s. 148.

8 Det har oppstått noen diskusjoner ang. akkurat denne norske betegnelsen og dens ekvivalenter i andre språk. (Jf. WILKUS 2015: 101-102). 
I utgangspunktet er «gjendiktning» en nøytral, håndverksmessig term som betegner overføringen fra et språk til et annet av et litterært verk som stiller såpass store krav (tropologiske, rimmessige, metriske, rytmiske) at man må ta seg atskillige friheter med originalens ordvalg. Men det har også fått karakter av å være et hedersord; den som bedriver «gjendiktning» er tilsynelatende mer kreativ enn den som sysler med oversettelser (HAGERUP 2005: 6-7).

I tråd med begrepsforklaringen hentet fra Litterært leksikon: begreper og betegnelser kan vi definere en gjendiktet tekst som et sted «hvor det ordrette ikke lenger spiller den primære rollen, for den forveksles med SAMMENFALL av betydning og det poetiske» (AARNES 1977: 84-85). Sånn sett åpner gjendiktningen seg også for de elementene som ligger utenfor selve skriften, dvs. den litteraturhistoriske konteksten, perseptuelle forventninger, men først og fremst KILDEKULTUREN. Konklusjonen som trekkes ut fra det ovennevnte kan være at en god oversetter, ved siden av å beherske begge språkene på høyest nivå, alltid har både originalens uforfalskete budskap og tekstens struktur i bakhodet, samtidig som han viser velvilje mot sine lesere. Prinsippets viktighet om å oppnå balansegang mellom innhold og form er dessuten primær for Selberg selv når han snakker om forskjellen mellom SEMANTISK-SYNTAKTISK og KOMMUNIKATIV OVERSETTELSE (RINDAL, FORMO, EGEBERG 1998: 242-243). Diskusjonen om frihetens grenser som aksepteres ved gjendiktningsprosessen pågår riktignok siden flere år, men sannheten er at verken utelukkende DET ORDRETTE eller SITT «EGNE» bør dominere målteksten. Martin Nag, tross det teoretiske, formulerer sitt eget «Credo» på en annen - la oss si djerv, måte:

Å gjendikte er - et kall... Et høytidelig ord? - gjerne det... Men i hvert fall jeg gjendikter ikke noe, hvis jeg ikke «føler meg kallet» til det... Og da står du fullstendig fritt vis-à-vis «objektet», total frihet! Selvsagt - dette krever gjensidig tillit, gjenklang, empati... Satt på spissen: Hvis ikke en dikter «har satt merker» i deg, skal du ikke gjendikte ham... (NAG 1994: 130)

I alle tilfeller er det likevel snakk om et gjensidig forhold mellom forfatteren og oversetteren, hvor den siste utvilsomt har en viktig formidlende rolle å spille. Jeg vil derfor analysere «Utopia» ved hjelp et nokså fleksibelt redskap som vil nærme meg et eller annet svar på spørsmålet om i hvor stor grad denne modellprosessen gjenspeiler virkeligheten.

\section{Aura - fra det diffuse ${ }^{9}$ til et forskningsredskap}

Som nevnt innledningsvis, støtter jeg meg i følgende undersøkelse på Walter Benjamins filosofisk-estetiske kategori AURA. Hensikten med akkurat dette valget er ikke minst termens omfang og flertydighet som på en sannsynliqvis uventet måte samler alle de ovennevnte aspektene ved oversettelsesvirksomet sammen, og knytter dem samtidig til diktets næranalyse.

9 De fleste Benjamin-kjennerne legger merke til forskjellige vansker man konfronteres med i løpet av Benjamins lesningen. Grunnen til det er nemlig veldig metaforiske og uklare formuleringer som tyskeren pleide å bruke. Mer om dette hos: FULD (1979); DURZAK (2016); LIPSZYC (2012); LINDNER (2006). 
Når man følger omdannelsen av begrepet AURA, blir man med en gang slått av varierende formuleringer, og framfor alt KONTEKSTER som den tyske tenkeren satte dette i. De aller første sporene på DET AURATISKE stammer fra 1930-åra, da Benjamin drev med forskningen på rusmidlers perseptuelle innflytelse. Riktignok må vi betone at auraens historie er mye lengre og har sine røtter allerede i antikken (BARCK et al. 2000: 404), men det er nettopp Benjamin som omsider gjorde den til en «håndgripelig» estetisk kategori. I selve begynnelsen av sin synlige granskning stiller filosofen seg følgende spørsmål: «- hva er egentlig aura? En selsom sammenvevning av rom og tid: en unik tilsynekomst av noe fjernt, så nær det enn er» (BENJAMIN 1975: 73). Ordleggingen fra notater om hasjisj lyder derimot:

For det første dukker den ekte aura opp på alle ting. Ikke bare på de bestemte som mennesker innbiller seg. For det andre forandrer auraen seg fullstendig og til bunns med hver bevegelse tingen utfører, hvis den har aura (BENJAMIN 1972: 107).

Ærlig talt er det vel umulig å gjøre en faktisk bruk av aura som hjelpemiddel, hvis man utelukkende baserer seg på disse to fragmentene. Heldigvis utvikles denne filosofien videre i retning noe mer «konkret», og noe som ikke lenger gjelder bare gjenstander (de såkalte «alle ting») sett i romlig og temporalt perspektiv, men den blir også forbundet med møtet mellom mennesker og naturen. Auraen skisserer seg altså som både en øyeblikkelig opplevelse og et gjensidig forhold mellom betrakteren og det betraktede, som Benjamin med tidens løp løfter opp til det man «erfarer». Med andre ord sier vi at aura karakteriserer spenningen ${ }^{10}$, og for å oppleve den, må noen betingelser bli oppfylt. Følgelig lar begrepets essens samle seg i noen hovedpåstander som jeg for artikkelens skyld velger ut fra flere mindre teorier angående aura-fenomenet:

Siden aura dukker opp kun der hvor det er snakk om et «ekte», «autentisk» kunstverk, har masseproduksjon ifølge filosofen ødelagt verkets individuelle og unike natur ${ }^{11}$. Konsekvensen er da at håndverkerens opprinnelige innsats i skapelsesprosessen, som i tillegg bestemte auraens overføring overfor et verk, ble mistet helt ugjenkallelig.

Merknaden om auraens plassering i tid og rom blir ellers presisert i det berømte kunstverksessayet. Der skriver Benjamin nettopp om hvordan auraen trer inn i møte mellom subjektet og objektet:

Ett moment mangler selv ved den mest fullkomne reproduksjon: kunstverkets Her og $N a ̊$ - dets unike eksistens på det sted hvor det befinner seg. I denne unike eksistens, og intet annet, sammenfattes kunstverkets historie i den tid det har bestått. [...] Originalen Her og Nå danner begrepet om dets ekthet (BENJAMIN 1975: 39-38).

10 Den kjente setningen om gjenstander som kaster sine blikk overfor betrakteren (og motsatt) finner vi i essayset om Baudelaire: BENJAMIN (1991: 464).

11 Denne beskrivelsen faller ved nærmere ettertanke sammen både med litteraturvitenskapelig syn på en tekst og med Brigitte Schultze sin teori om forfatterens individuelle estetikk. Der fokuserer hun på ulike KonTEKSTER, dvs. visse sammenhenger som både forfatteren og oversetteren har rotfester i. Se: (SCHULTZE 2005: 860-896). 
Med andre ord synes aura-opplevelsen å være umulig hvis kunstverket ikke befinner seg i en bestemt kontekst, samtidig som det granskes av et subjekt. Selvsagt er tradisjonnssammenhengen en størrelse som også blir utsatt for tidens løp - selv om kunstverket på den ene side har sine røtter i det kultiske, tradisjonelle og historiske, eksisterer det på den annen side akkurat $d a$ når mottakeren kaster sitt blikk på det.

Til syvende og sist overfører Benjamin auraen også på det språklige nivået, og disse overveielsene binder fenomenet enda sterkere med allslags tekstanalyse. Utgangspunktet for hans auratiske språkfilosofi ligger ikke minst i språkets performative karakter. Det betyr ikke noe annet enn det at den egentlige meningen kommer til syne gjennom ordets skjulte uttrykkskraft - framfor det som språket tilsynelatende uttaler. Men Benjamin peker ellers på en annen form for aura. Vårt mål har nemlig en underlig egenskap til å forskyve og omdanne de kjente betydningene, det løsriver ting fra konvensjonens stive rammer og det er derfor at skriftens livsbekreftende aspekt fører oss til auraen (REINTON 2009: 141). Hva bidragets problemstilling angår, kan «det unike» ved språket betrakets som Überhang an Bedeutung (JOKIEL 2007: 56) - noe «mer» som lesere vil få tilgang til.

Setter vi alle disse dimensjonene inn i gjendiktningskontekst, kommer vi til følgende slutninger:

I kraft av påstanden om at alle ting kan kalles «aurabærende» (JOKIEL 2007: 56), og for øvrig med tanke på at poesien - i takt med dens gjendiktning, i sitt vesen tilhører tradisjonen, er auraens nærvær i originalen (muligens også i dens overføring) noe apriorisk gitt. Ikke nok med det, det ovennevnte befester auraens oppstandelse ved bruken av språklige virkemidler - forstått som fravær (f.eks. ellipse) eller som enkle menningsbærende elementer (metaforer, konnotasjoner o.l.). For øvrig glemmer vi heller ikke at fenomenets potensial utspiller seg i det forholdsmessige. Hver gang en leser møtes med skriften, skjer dette på et bestemt tidsspunkt og på et bestemt sted. Det er derfor leseakten konstituerer Her og $N a ̊$, men nokså viktig fører denne handlingen til omdannelsen av de kjente ordforbindelsene (konnotasjoner og erindringens bilder som da utløses, alltid tilhører den subjektive sfære).

\section{Diktets auratiske analyse}

Nesten enhver innledning til kritiske refleksjoner over overføringen av «Utopia» begynner med følgende konstatering: Det vanskeligste i oversettelsen av dette diktet er utvilsomt dets brutte fraseologismer som Szymborska brukter altfor ofte (BRAJERSKA-MAZUR 2012: 81). Det første problemet som en norsk oversetter konfronteres her med er, overraskende nok, termen FRASEOLOGISME. De som sysler med overføringen av «Utopia» til norsk, kjenner sikkert til forskjellige kritiske tekster om dette verket, og er derfor helt klare over hva fraseologisme egentlig er. Men for å være presis må jeg understreke at dette begrepet ikke finnes i det norske språksystemet. Man kan riktignok lese om fraseologi på dansk ${ }^{12}$, men

12 Jf. Den Store Danske: http://denstoredanske.dk/Sprog,_religion_og_filosofi/Sprog/Morfologi_og_syntaks/fraseologi (tilgjengelig 1.06.2016). 
synonymt bruker de norske snarere betegnelsen «faste uttrykk» eller «faste vendinger». Ut fra flere vitenskapelige forslag definerer jeg fraseologismer rett og slett som slike leksikalske enheter som ved siden av å berike eller forsterke det billedlige i teksten, fordrer også å kjenne både til elementenes enkle betydninger og deres mulige meninger sett i større sammenhenger (BARAN 2012: 200). Inn i denne kategorien faller dessuten ulike ordspill, dvs. sammensatte leksemer som helt bevisst korresponderer med kjente ordforbindelser eller bryter med dem for å danne en ny betydningsenhet ${ }^{13}$.

Det er vel ikke en hemmelighet at $\mathrm{i}$ «Utopia» er det akkurat faste ordforbindelser som utgjør helhetens konsept. Bruken av sånne språklige spill er forresten noe typisk i Szymborskas forfatterskap (BINKOT, SZCZESSNA 2012: 100-105). Sånn sett bør ingen oversetter la seg bli ført inn i fristelse og følge det tilsynelatende enkle, nesten naive språket, uten nærmere ettertanke. Siden Szymborskas lyrikk hovedsakelig består av frie vers, setter litteraturforskere det semantiske aspektet i fokus (WIŚNIOWSKA 2014: 112) og legger dermed vekt på det meningsbærene samspillet mellom ordene og/eller uttrykkene.

La oss altså etterspore i hvilken grad Selberg har klart å formidle originalens auratiske vendinger til norsk.

«Utopia»

(Wielka liczba, 1976)

Wyspa na której wszystko się wyjaśnia.

Tu można stanąć na gruncie dowodów.
«Utopia ${ }^{14}$

(1996:104)

Øya hvor alt får sin forklaring.

Den markerte verslinjen fra første strofe kan i utgangsteksten forstås både ordrett og metaforisk. Hele diktet skildrer nemlig ei øy hvor det topologiske og det erkjennelsesmessige (i betydning filosofisk verdensoppfatning) beløper seg til to semantiske felter. Som følge av dette kan man like godt "stå på en fast grunn», men ellers «føle seg trygg» i overført betydning. Mens uttrykkets metaforiske tolkning er samme på norsk (etter $B o k-$ målsordboka: «være trygg (igjen)»), bestemmer Selberg seg for å gjøre dette bildet mer dynamisk ved hjelp av verbet «trå». Transformasjonen inne denne verslinjen virker likevel litt overraskende, for i begge språkene viser ordbøkene snarere til en stabil tilstand (på norsk heter det «få fast grunn under føttene»). Szymborska ville trolig plassere subjektet i en ny virkelighet på et trygt og modig vis, som i sitt vesen legger et solid grunnlag for øyas videre inspisering. Selberg, derimot, begynner diktet med et mildere bilde, og viser dermed at den besøkende først har begynt å venne seg til det nye stedet.

13 Jf. BOBKOVÁ (2013: 33-44).

14 Siden de fleste formuleringene ble oversatt ganske ordrett, finnes det ikke noe behov for å føye egne forslag til. Ellers skal jeg komme med eventuelle kommentarer i hovedteksten (nøkkelordene med halvfet skrift - mine markeringer). 
Nie ma dróg innych oprócz drogi dojścia.

Rośnie tu drzewo Słusznego Domysłu o rozwikłanych wiecznie gałęziach.
Her fører alle veier til målet.

Her vokser Den riktige antagelses tre med sine fra evighet av utredede grener.

Neste verslinje bringer likevel større vansker. Helt fysisk passer begge versjonene til diktets topologisk karakter, men konnotasjonen som de polsktalende med én gang får inn i hode, dvs. «å komme seg til sannheten», forblir helt uleselig på norsk. De mest vanlige uttrykkene knyttet til ordene «føre» og «vei» går snarere i retning «alle veier fører til Rom(a)». I tillegg kan dette peke på alle forbindelser med substantivet «et mål», f.eks. «uten mål og mening» og «målet helliger midlet» (ERICHSEN 2011: 145-146). Omsider mister vi i norsk oversettelse den epistemologiske gjenklangen, og i dette tilfellet kan man vel snakke om et betydelig bortfall av originalens skjulte mening. I siste verslinje av denne strofen kommer Selberg ikke desto mindre med et interessant forslag om å gripe inn i en typisk syntaktisk konstruksjon. En sånn uvanlig måte å sette en adjektivfrase foran subjektet minner nemlig om den språklige kansellistilen med røtter i DanmarkNorges historie. Nå til dags bruker man betegnelsen «kansellistil» nokså nedsettende for å nevne noe innviklet, stivt, og fremfor alt arkaisk. I gjendiktningen synes denne ideen tvert imot å være gjennomtenkt og samsvarende med originalen. Fordi utgangsspråket hos Szymborska virker litt gammeldags, kan denne uttrykksmåten kalles diktets konsept. Her fortjener Selberg altså å bli taksert for sin trofaste stilling overfor originalen.

Im dalej w las, tym szerzej się otwiera Dolina Oczywistości.
Jo lenger man kommer inn i skogen desto bredere blir Selvølgelihetens dal.

Jeśli jakieś zwątpienie, to wiatr je rozwiewa. Finnes det noen tvil, væres den hen av vinden.

Echo bez wywołania głos zabiera

Ekkoet griper ukallet ordet.

Hva konnotasjoner til «skogen» angår, oppstår det igjen markante forskjeller mellom begge språkene. Alt dette grunnet en iøynefallende polsk fraseologisme «jo lenger inn i skogen, jo flere trær». Metaforisk sett viser den til stadig flere vanskeligheter som man opplever etter å ha engasjert seg i en sak. I forbindelse med «Selvfølgelighetens dal» danner de sammen et spennende bilde av erkjennelsesmuligher bygget opp på oksymoronen. Den norske fremstillingen peker riktignok i retning uttrykkets opphavlige semantikk, men dets henvisning til Szymborakas lek med konvensjonell sprakbruk kjennes ikke igjen på norsk.

«Rozwiewanie wątpliwości» fra linjen nedenfor er neste ordspill med faste vendinger. Her foregår nemlig spenning mellom uttrykkene «vinden blåser noe bort» og «blåse bort all tvil» som på polsk brukes både i dagligtale og skriftspråk. Selbergs versjon med verbet «være hen» høres her nokså kunstig og er heller ikke gjenkjennelig ut for vanlige språkbrukere. 
Mimo powabów

wyspa jest bezludna,
Tross alle attraksjoner

er øya øde.

Det som jeg allerede har verdsett i Selbergs syntaksbruk, forsvinner dessverre i diktets siste del grunnet en liten avvik - hos Szymborska lokker øya sine besøkende, men dens sjarme forblir oversett. Den samme situasjonen presenterer også den norske teksten, mens her med én betydelig forskjell: Ordet «attraksjoner» virker veldig moderne, dette samler rundt seg og fremkaller hverdagslig stilnivå som i første rekke gjelder turistbransjen. Sant nok er det nettopp i den retning originalens betydning streber mot, men det er fremdeles ordstilens nivå som bestemmer fremstillingens egentlige bilde.

Jak gdyby tylko

odchodzono stąd

i bezpowrotnie zanurzano się w topieli.
Som om folk bare har gått

bort herfra

og for alltid

dukket ned i dypet.

Omsider kommer vi til «Utopias» hjerte, hvor hele «det skjulte» og «det unike» gjemmer seg bak skriften. Poenget med dette diktet ligger nemlig i samspillet mellom polske betegnelser «topiel», som betyr «et havdyp» (hos Selberg «dypet»), og som opprinnelig er knyttet til verbet «utopić». Setter vi disse ordene sammen, viser det seg at tittelens «Utopia» egentlig refererer til handlingen å dukke noen eller noe ned. Den type enestående sammenfall av betydninger og lyder er dog uoversettbart - det må man dessverre ta for gitt fordi fullstendig likeverdige synonymer er vanskelige å etterspore sågar innen ett språksystem (BĄK 2007/2008: 34-37). Den trolig best oppsummerende kommentaren til dette formulerte en gang Anders Bodegård, som med stor skuffelse konstaterer at i hans morsmål er det helt umulig «å drukne utopia» (BALBUS 1996: 17). Likevel fortjener Selberg en positiv respons på alliterasjonen han innfører for å beholde i muligens høyeste grad originalens form og innhold.

\section{Avsluttende bemerkninger}

På spørsmålet om Ole Michael Selberg har klart å formidle diktets aura - eller sagt med andre ord, om han var i stand til å overføre den type erfaring som en polsk leser er utsatt for under lesningen i bestemte omstendigheter (dvs. rom og tid), er svaret tosidig. Det finnes vel sånne grammatiske, semio- og semantiske ulikheter som til og med den mest erfarne gjendikteren ikke kan overvinne. Og nettopp der er det plass for hans kreativitet (BOBKOVÁ 2013: 42), språklige sansers triumf og yrkesmessig intuisjon. På den grunnlag ser vi at Selberg i de fleste tilfellene har greid å gjenspeile de primære semantiske elementene av innholdet, hvor bortfallet av den unike aura-tilsynekomsen skyldes objektive hindringer. Men det å skifte stilnivået eller gripe inn i formuleringer som på enkelt vis 
kunne ha blitt betraktet med større tilbøyelighet til likeverdighet, har også skjedd. Det som samtidig ikke kan benektes er at Selbergs prøver om å ha oversettelses relasjonelle aspekt i bakhodet, har i fleste verslinjer lyktes. Gjentar man Sylfest Lomheim sine bemerkninger til budskapsoverføring, synes den norske utopien å komme i en synlig dialog mellom tekst og forfatter ${ }^{15}$; Selv om hovedbudskapet også strekker seg ut på et metanivå, måtte Selberg tre inn med noen konstruktive forslag om nye uttrykks- og ordforbindelser på norsk. Og da ble betingelsen ang. språkets auratiske nyskapning selvfølgelig oppfylt.

Som en liten oppmuntring til alle med ambisjoner i å overføre poetiske tekster - særlig Szymborskas verk, anbefaler jeg å se nøyere på en setning hentet fra Selbergs etterord til Utsikt med et sandkorn: «Szymborska er skeptisk til alle utopier og ideologier, og forsvarer den enkeltes rett til å gå sine egne veier» (SELBERG 1996: 147).

\section{Referanseliste:}

AARNES, Asbjørn (1977): Litterært leksikon begreper og betegnelser. Teori - Kritikk - Historie. (Kunnskapsforlaget) Oslo.

BALBUS, Stanisław (1996): ,Słowo wstępne‘. In: BALBUS, Stanisław \& WOJDA Dorota (Eds.): Radość czytania Szymborskiej. Znak. Kraków, s. 7-19.

BARAN, Katarzyna (2012): Polskie frazeologizmy w słoweńskich przekładach wierszy Wisławy Szymborskiej. In: Przekłady Literatur Słowiańskich. Bariery Kulturowe W Przekładzie Artystycznym 3(1), s. 200-215.

BARCK, Karlheinz, FONTIUS, Martin, SCHLENSTEDT, Dieter, STEINWACHS, Burkhart, \& WOLFZETTEL, Friedrich (2000): Ästhetische Grundbegriffe. Historisches Wörterbuch in sieben Bänden. Band 1. (J. B. Metzler Verlag) Stuttgart/Weimar.

BĄK, Paweł (2002): Korekta języka jako wyzwanie i technika w przekładzie. In: Rocznik Przekładoznawczy 3/4, s. 33-49.

BENJAMIN, Walter (1975): Kunstverket i reproduksjonsalderen: essays om kultur, litteratur, politikk. (Gyldendal) Oslo.

BENJAMIN, Walter (1972): Über Haschisch. Novellistisches, Berichte, Materialien. (Suhrkamp Verlag) Frankfurt am Main.

BENJAMIN, Walter (1991): Gesammelte Schriften I. (Suhrkamp Verlag) Frankfurt am Main.

BINKOT, Anna, \& Szczęsna, Joanna (2012): Co wiersz, to problem. O tłumaczach i thumaczeniach. In: Miesięcznik Znak 5(684), s. 100-105.

BOBKOVÁ, Milada (2013): Übersetzungmöglichkeiten und Rolle der Kreativität beim Übersetzen der Phraseologismen im Künstlerischen Text. In: Brünner Beiträge Zur Germanistik Und Nordistik 1-2(1932), s. 33-44.

BODEGÅRD, Anders (2014): Wolę umarlych bo z nimi nie ma żadnego problemu. In: Wiadomości ZAiKSu 7, s. 28.

BRAJERSKA-MAZUR, Agata (2012): "Filutka z filigranu”. O przekładzie językowego naśladownictwa z ekfrastycznych wierszy Wisławy Szymborskiej. In: Pamiętnik Literacki 1, s. 187-219.

BRODSKIJ, Iosif (1997): Hvordan lese en bok : essays. (Aventura) Oslo.

DURZAK, Manfred (2016): Walter Benjamin und die Literaturwissenschaft. In: Monatshefte 58(3), s. 217-231.

15 Lomheim ord lyder: «Me jamfører produktet, versjonen, med originalen. Viss versjonen formidler same bodskap som originalen, då har vi ekvivalens (likeverd)». (LOMHEIM 1989: 71). 
EGGEN, Arnljot, \& NAG, Martin (1967): Den Sjuande engelen. Eit utval frå polsk etterkrigslyrikk. (Samlaget) Oslo.

ERICHSEN, Gerta Moter (2011): Ord og uttrykk på fire språk. (Cappelen Akademisk Forlag) Oslo. FULD, Werner (1979): Zur Gedichte eines Begriffes bei Benjamin. In: Akzente 26, s. 352-370.

HAGERUP, Henning (2005): Som feiere til støvet gå. In: Vagant 3, 6-20.

JOKIEL, Małgorzata (2007): Transformation der Weltbilder in den polnischen Übersetzungen der Romane von Franz Kafka. (Wydawnictwo Uniwersytetu Opolskiego) Opole.

KITTANG, Atle \& AARSETH, Asbjørn (1998): Lyriske strukturer : Innføring i diktanalyse. 4. utgave. (Universitetsforlaget) Oslo, s. 11-14.

LINDNER, B. (2006): Das Kunstwerk im Zetalter seiner technischen Reproduzierbarkeit. In: Benjamin - Handbuch. Leben, Werk, Wirkung. (J.B. Metzle) Stuttgart/Weimar, s. 229-251.

LIPSZYC, Adam (2012): Sprawiedliwość na końcu języka. Czytanie Waltera Benjamina. (Universitas) Kraków.

LOMHEIM, Sylfest (1989): Omsetjingsteori. (Universitetsforlaget) Trøgstad.

MRÓWCZYŃSKA, Emilia (2014): Wiersz Wisławy Szymborskiej „Nic dwa razy” w thumaczeniach na jezyk szwedzki. (Stockholms universitet) Stockholm.

NAG, Martin (1997): Alltid et fragment : dikt, dagbok-notater, gjendiktninger. (Solum) Oslo.

NAG, Martin (1994): Menneskeåndens revoltering! (Solum) Oslo.

REINTON, Ragnhild Evang (2009): Georges Perec og erindringens $(\{\ldots\})$. In: Norsk Litteraturvitenskapelig Tidsskrift 12(2), s. 121-143.

RINDAL, Magnus, FORMO, Tone, \& EGEBERG, Erik (1998): Brobyggere. Oversettelser til norsk fra middelalderen til i dag. (Aschehoug) Oslo.

RØED, Ragnar (1970): Polen i norsk litteratur : bibliografi. (Universitetsforlaget) Oslo.

SCHULTZE, Brigitte (2005): Kontexte in der literarischen Übersetzung. In: H. Kittel \& A. P. Frank (Eds.), Übersetzung. Ein internationales Handbuch zur Übersetzungsforschung. 1. Teilbd. (De Gruyter) Berlin, New York, pp. 860-896.

SELBERG, Ole Michael (1991): Polsk litteratur i norsk oversettelse 1826-1989. En bibliografi. (Universitetsforlaget) Oslo.

SZYMBORSKA, Wisława (1996): Utsikt med et sandkorn. (Solum) Oslo.

STRØM, Cathrine, \& VIKØY, Aasne (Eds.) (2009): Mellomrom II: omsetjaren Olav H. Hauge. (TransFe:r Forlag) Bergen.

VIKØY, Aasne, STRØM, Cathrine, \& ROKSETH, Benjamin (Eds.) (2007): Mellomrom - tolv tekster om oversettelse. (TransFe:r Forlag) Oslo.

WILKUS, Aleksandra (2015): Poeta vs poeta-tłumacz. O niemieckim i norweskim przekładzie wiersza Czesława Miłosza “Campo di Fiori.”. In: Rocznik Karla Dedeciusa VIII, 99-110, s. 101-102.

WIŚNIOWSKA, Marta (2014): Przekładając nieprzekładalne - modyfikacje frazeologizmów w wierszu "Utopia” Wisławy Szymborskiej w przekładzie Karla Dedeciusa. In: K. Kuczyński (Ed.), Rocznik Karla Dedeciusa. (Archiwum Karla Dedeciusa) Łódź, s. 111-120.

Aleksandra Wilkus-Wyrwa / aleksandra.wilkus@amu.edu.pl

Ph.D-candidat, Department of Scandinavian Studies, Adam Mickiewicz University

Al. Niepodległości 4, 61-874 Poznań, Poland 
